\title{
SISTEM PENUNJANG KEPUTUSAN PENENTUAN KARYAWAN TERBAIK PADA PT. ENERGI SINAR SENTOSA DENGAN METODE ANALYTICAL HIERARCHY PROCESS DAN SIMPLE ADDITIVE WEIGHTING
}

\author{
Adi Widiyanto $^{1)}$, Humisar Hasugian ${ }^{2)}$ \\ ${ }^{1}$ Sistem Informasi, Fakultas Teknologi Informasi, Universitas Budi Luhur \\ ${ }^{1,2} \mathrm{Jl}$. Raya Ciledug, Petukangan Utara, Kebayoran Lama, Jakarta Selatan 12260 \\ E-mail : $\underline{\text { adiwidy82@gmail.com }}{ }^{1)}$, humisar.hasugian@budiluhur.ac.id ${ }^{2)}$
}

\begin{abstract}
Abstrak
Karyawan merupakan tenaga kerja yang memiliki tugas untuk menjalankan sebuah aktivitas yang telah diatur sesuai dengan kebutuhan perusahaan. Pengelolaan Sumber Daya Manusia dari suatu perusahaan sangat mempengaruhi tingkat keberhasilan dari suatu perusahaan. PT. Energi Sinar Sentosa adalah perusahaan yang bergerak di bidang supplier pelumas kendaraan. Untuk meningkatkan kinerja para karyawan, perusahaan akan memberikan subuah reward kepada karyawan sebagai apresiasi atas kinerjanya yang maksimal. Namun pada perusahaan ini belum memiliki suatu metode yang digunakan untuk menentukan karyawan terbaik dan masih menggunakan cara manual dengan menentukan satu kriteria untuk menjadi acuan penilaian. Penelitian ini bertujuan untuk membuat suatu Decision Support System (DSS) dengan metode analytical hierarchy process (AHP) dan Simple Additive Weighting (SAW) berbasis web yang dirancang menggunakan Hypertext Preprocessing (PHP), dan database MySQl untuk mempermudah dalam pemilihan karyawan terbaik. Metode analytical hierarchy process (AHP) digunakan untuk penentuan bobot dari kriteria-kriteria yang sudah ditentukan oleh perusahaan dan Simple Additive Weighting (SAW) untuk perangkingan.
\end{abstract}

Kata kunci: DSS, Karyawan, Metode AHP, SAW.

\section{PENDAHULUAN}

Karyawan merupakan tenaga kerja yang memiliki tugas untuk menjalankan sebuah aktivitas yang telah diatur sesuai dengan kebutuhan perusahaan. Pengelolaan Sumber daya manusia sangat penting untuk keberlangsungan suatu perusahaan. Oleh karena itu sumber daya manusia dapat mempengaruhi tingkat keberhasilan dari suatu perusahaan dalam menjalankan semua proses usahanya. Untuk meningkatkan kinerja para karyawan, perusahaan akan memberikan apresiasi berupa subuah reward kepada karyawan yang dinilai telah memberikan kinerja yang sangat baik untuk perusahaan. PT. Energi Sinar Sentosa merupakan sebuah perusahaan yang bergerak dibidang supllier pelumas kendaraan bermotor. Pada perusahaan ini belum memiliki suatu metode tertentu untuk menentukan karyawan terbaik. Pemilihan karyawan terbaik disini, ditentukan dengan cara manual dan hanya menggunakan satu kriteria saja. Untuk itu sistem pendukung keputusan bisa dijadikan solusi dalam pemilihan karyawan terbaik. Dari permasalahan diatas maka dibuatkan sistem penunjang keputusan menggunakan metode Analytical Hierarchy Process (AHP) dan Simple Additive Weighting (SAW). Metode Analytical Hierarchy Process (AHP) digunakan untuk menentukan bobot dari setiap kriteria. Sedangkan metode Simple Additive Weighting (SAW) digunakan untuk perangkingan agar mendapatkan hasil dari penentuan karyawan terbaik.

\section{METODE PENELITIAN}

\subsection{Metodologi Penelitian}

Dalam penelitian ini, penulis mengumpulkan data dengan beberapa metode, yaitu observasi, wawancara studi literature dan kuesioner.

a. Observasi

Metode ini dilakukan untuk mengumpulkan data dengan cara mengamati langsung hal-hal yang berkaitan dengan proses penentuan karyawan terbaik pada PT. Energi Sinar Sentosa.

b. Wawancara

Wawancara merupakan proses pengumpulan data kepada manager dengan mengajukan pertanyaan-pertanyaan secara langsung yang akan membantu dalam pembuatan sistem penunjang keputusan pada penilitian ini. Pertanyaan yang diajukan kepada manager diantaranya mengenai permasalahan yang berkaitan dengan penentuan karyawan terbaik dan kriteria yang akan digunakan.

c. Studi Literatur

Kegiatan ini dilakukan dengan mengumpulkan dokumen-dokumen sebagai acuan seperti buku, jurnal, artikel atau dokumen lainnya yang telah dipublikasi, dan juga literatur tugas akhir yang berkaitan dengan teori penentuan karyawan terbaik, 
teori sistem penunjang keputusan, teori Analytical Hierarchy Process (AHP), dan teori Simple Additive Weighting (SAW).

d. Kuesioner

Kuesioner merupakan pengumpulan data dengan mengajukan pertanyaan tertulis kepada manager untuk menentukan perbandingan kepentingan antar kriteria yang sudah ditentukan untuk menetukan karyawan terbaik..

\subsection{Instrumensatasi}

Pada penelitian ini, penulis menggunakan kuesioner sebagai instrumentasi. Kuesioner digunakan untuk menentukan tingkat kepentingan antar kriteria untuk menentukan bobot dari kriteria dengan metode Analytical Hierarchy Process (AHP).

\subsection{Teknik Analisa Data}

Teknik yang digunakan pada penelitian ini adalah Analytical Hierarchy Process (AHP), dan Simple Additive Weighting (SAW). Analytical Hierarchy Process (AHP) digunakan untuk mencari/ menentukan bobot dari masing-masing kriteria yang telah ditentukan karena PT. Energi Sinar Sentosa belum memberikan pembobotan kriteria. Simple Additive Weighting (SAW) digunakan untuk perangkingan dari setiap alternatif setelah kriteriakriteria diolah.

\subsection{Studi Literatur}

a. Penulis Humisar Hasugian, Zahrina Nisa Sabila dengan judul "Penerapan Metode AHP dan SAW Dalam Pengambilan Keputusan Pemilihan Supplier Bahan Jaket Pada CV. Widia Pratama Kreasi" diterbitkan oleh Universitas Ibn Khaldun pada tahun 2018. Penelitian ini bertujuan untuk menghasilkan suatu sistem penunjang keputusan untuk membantu menyeleksi supplier dengan tepat [1].

b. Penulis Yuli Astuti, Isna Zahrotul Fuad dengan judul "Penentuan Karyawan Terbaik Menggunakan Metode Simple Additive Weighting pada PT. Patra Nur Alaska” diterbitkan oleh STMIK AMIKOM Yogyakarata pada tahun 2017. Penelitian ini bertujuan untuk menghemat waktu dalam penilaian dan mendapatkan hasil yang objektif [2].

c. Penulis Alex Rikki, Murni Marbun, Jonson R.Siregar dengan judul "Sistem Pendukung Keputusan Penerimaan Karyawan Dengan Metode SAW pada PT. Karya Sahata Medan” diterbitkan oleh Journal of Informatics Pelita Nusantara (JIPN) pada tahun 2016. Penelitian ini bertujuan untuk mempermudah penentuan karyawan dengan tingkat akurasi yang tinggi dan dapat menghemat waktu pemilihan [3].

\section{HASIL DAN PEMBAHASAN}

\subsection{Profil Organisasi}

PT. Energi Sinar Sentosa adalah salah satu perusahaan swasta nasional indonesia yang bergerak di bidang penjualan pelumas kendaraan. PT. Energi Sinar Sentosa didirikan pada tanggal 15 Agustus 2018 oleh Bpk. Suyoto dan berlokasi di Jakarta.

a. Visi :

Menjadi salah satu perusahaan yang berkembang untuk mencukupi kebutuhan pelanggan dan menjadi perusahaan nasional kelas dunia.

b. Misi :

Memberikan kinerja profesionalisme dalam operasional untuk melayani pelanggan dengan kualitas terbaik yang sesuai dengan takaran, standar mutu dan tepat waktu.

\subsection{Analisa Pembahasan}

Pada gambar 1 merupakan rancangan fishbone diagram. Masalah utama pada penelitian yang dilakukan pada PT. Energi Sinar Sentosa adalah penentuan karyawan terbaik yang masih belum tepat sasaran yang dipengaruhi oleh beberapa faktor manusia, faktor proses dan faktor metode. Faktor manusia mengakibatkan menurunnya produktivitas kerja para karyawan yang disebabkan karena pemilihan karyawan terbaik yang tidak akurat. Faktor proses mengakibatkan hasil penentuan yang terbilang menjadi subjektif dikarenakan proses pengambilan keputusan menggunakan satu kriteria saja. Faktor metode mengakibatkan hasil pengambilan keputusan tidak akurat disebabkan belum adanya metode tertentu yang digunakan untuk menentukan karyawan terbaik.

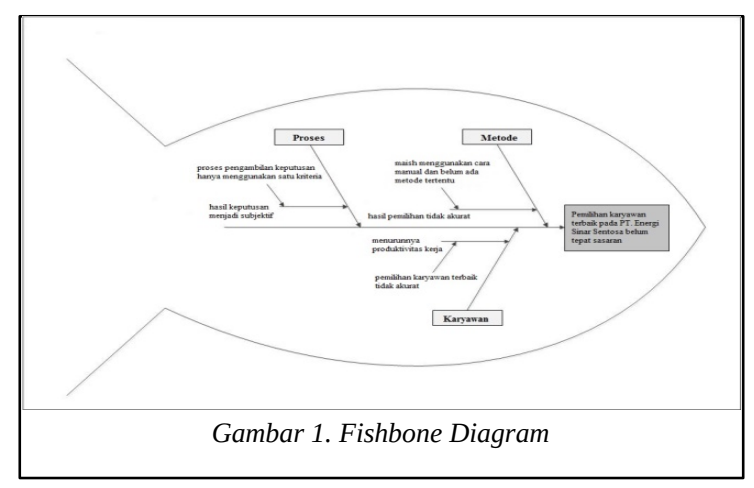




\subsection{Proses Bisnis}

Pada gambar 2 adalah activity diagram proses bisnis. Proses dimulai dari manager menentukan kriteria apa yang akan dijadikan sebagai acuan untuk menentukan karyawan terbaik setiap bulannya, lalu manager akan melakukan penilaian terhadap karyawan, kemudian setelah selesai, manager akan memutuskan siapa karyawan yang layak menjadi pemenang untuk periode tersebut, kemudian manager akan mengumumkan dan memberikan reward sebagai hadiah untuk pemenang karyawan terbaik di periode tersebut.

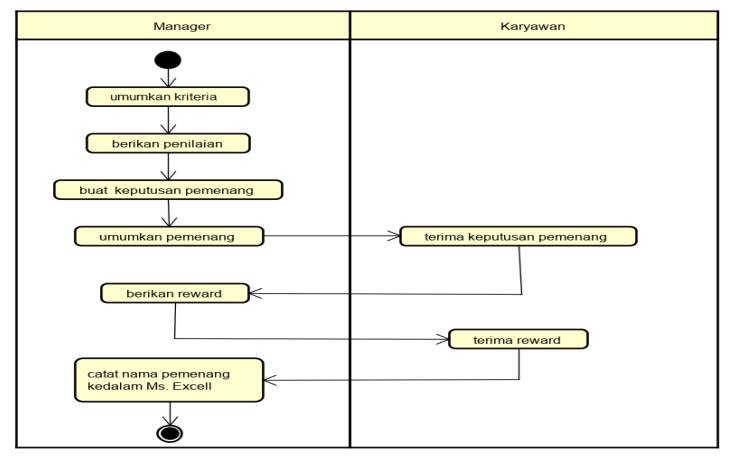

Gambar 2. Activity Diagram

\subsection{Model Analytical Hierarchy Process (AHP)}

Proses Hierarki Analitik (Analytical Hierarchy Process) dikembangkan oleh Dr. Thomas L. Saaty dari Wharton School of Bussines pada tahun 1970-an untuk mengorganisasikan informasi dan judgement dalam memilih alternatif yang paling disukai (Marimin dan Maghfiroh N, 2010) [4].

Pada gambar 3 adalah struktur hierarki permasalahan untuk penentuan karyawan terbaik pada PT. Energi Sinar Sentosa dengan beberapa kriteria dan alternatif.

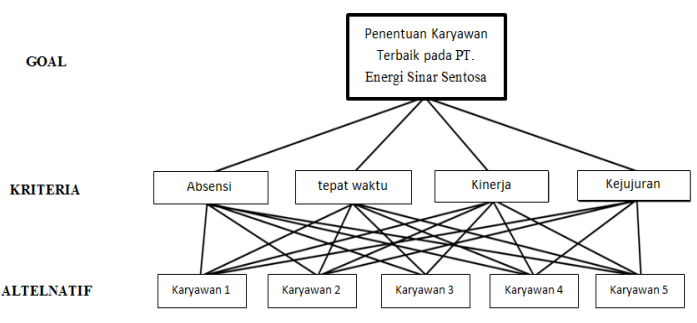

Gambar 3. Struktur Hierarki

\subsection{Perbandingan Kepentingan Antar Kriteria}

Berdasarkan kuesioner perbandingan kepentingan antar kriteria yang didapat dari manager, maka didapatkan tabel matriks perbandingan pada tabel 1:

Tabel 1. Matriks perbandingan antar kriteria

\begin{tabular}{lcccc}
\hline Kriteria & Absensi & Tepat waktu & Kinerja & Kejujuran \\
\hline Absensi & 1 & 3 & $1 / 3$ & $1 / 5$ \\
Tepat waktu & $1 / 3$ & 1 & $1 / 5$ & $1 / 7$ \\
Kinerja & 3 & 5 & 1 & $1 / 2$ \\
Kejujuran & 5 & 7 & 2 & 1 \\
\hline
\end{tabular}

\subsection{Pengujian metode Analytical Hierarchy}

\section{Process (AHP)}

Menghitung nilai Consistency Index (CI) dan nilai Consistency Ratio (CR) untuk melakukan pengujian terhadap metode AHP.

Menghitung nilai Consistency Index dengan menggunakan rumus :

$$
\begin{aligned}
& C I=\frac{(\pi-n)}{n-1} \mathrm{n}=\text { jumlah kriteria } \\
& C I=\frac{(4,0686-4)}{4-1} \\
& C I=0,0229
\end{aligned}
$$

Menghitung Consistency Ratio, membutuhkan nilai RI yaitu Random Index yang didapatkan dari table Oarkridge $C R=\frac{C I}{R I}$ untuk $\mathrm{n}=4$, maka nilai $\mathrm{RI}$ yaitu 0,90 .

$$
\begin{aligned}
& C R=\frac{0,0229}{0,90} \\
& C R=0,0254
\end{aligned}
$$

Jadi, nilai CR untuk kriteria penentuan karyawan terbaik pada PT. Energi Sinar Sentosa adalah 0,0254. Penilaian perbandingan dikatakan konsisten jika Consistency Ratio (CR) tidak lebih dari 0,1000 sehingga penilaian perbandingan kriteria penentuan karyawan terbaik pada PT. Energi Sinar Sentosa sudah konsisten dan tidak memerlukan revisi penilaian.

\subsection{Model Keputusan dengan Simple Additive Weighting (SAW)}

Pada tabel 2 adalah tabel penggolongan dan bobot kriteria. Metode Simple Additive Weighting (SAW) digunakan untuk menghitung nilai akhir dari masing-masing alternatif yaitu untuk menentukan karyawan terbaik. Keluaran yang akan dihasilkan adalah urutan penilaian alternatif dari nilai yang tertinggi hingga alternatif dengan nilai terkecil. Alternatif yang dimaksud adalah karyawan yang berkerja di PT. Energi Sinar Sentosa. Kriteria yang digunakan dalam penentuan karyawan terbaik dalam atribut keuntungan (benefit) dalam kasus ini terdiri adalah kinerja dan kejujuran, sedangkan atribut cost 
yaitu kriteria absensi dan tepat waktu. Setiap kriteria memiliki bobot yang sebelumnya telah ditentukan menggunakan metode Analytical Hierarchy Process (AHP) yang dihitung dalam matriks perbandingan antar kriteria pada tabel 1.

Tabel 2. Penggolongan dan bobot kriteria

\begin{tabular}{|c|c|c|c|}
\hline Kriteria & Benefit & Cost & Bobot \\
\hline Absensi & & $\bar{V}$ & $12,07 \%$ \\
\hline Tepat waktu & & V & $5.54 \%$ \\
\hline Kinerja & V & & $29,91 \%$ \\
\hline Kejujuran & V & & $52,48 \%$ \\
\hline
\end{tabular}

Berdasarkan banyak karyawan pada PT. Energi Sinar Sentosa, maka digunakan 5 (lima) sample karyawan untuk menerapkan metode simple additive weighting untuk mengambil keputusan karyawan terbaik. Pada tabel 3 merupakan nilai alternatif pada setiap kriteria.

Tabel 3. Nilai Alternatif pada setiap Kriteria

\begin{tabular}{lcccc}
\hline \multirow{2}{*}{ Alternatif } & \multicolumn{4}{c}{ Kriteria } \\
\cline { 2 - 5 } & Absensi & Tepat waktu & Kinerja & Kejujuran \\
\hline Darus Salam & 0,1 & 2 & 3 & 5 \\
Nur Oktaviani & 2 & 1 & 4 & 4 \\
Vera Larasati & 1 & 4 & 3 & 3 \\
Murniati & 0,1 & 3 & 4 & 4 \\
Via Sumantia & 3 & 2 & 5 & 4 \\
\hline
\end{tabular}

Lakukan normalisasi untuk menghitung nilai masing-masing kriteria, menghitung berdasarkan kriteria keuntungan (benefit) atau kriteria biaya (cost) dengan persamaan sebagai berikut:

$$
r_{i j}=\left\{\begin{array}{l}
\frac{X_{i j}}{\operatorname{Max}_{i} X_{i j}} \text { Jika jatribut keuntungan }(\text { benefit }) \\
\left.\frac{\operatorname{Min}_{i} X_{i j}}{X_{i j}} \text { Jika jatribut biaya } \mid \text { cost }\right)
\end{array}\right.
$$

Berikut adalah perhitungan kriteria yang bernilai cost.

$$
\begin{aligned}
& \mathrm{R} 11 \frac{\min (0,1 ; 2 ; 1 ; 0,1 ; 3)}{0,1}=\frac{0,1}{0,1}=1,0000 \\
& \mathrm{R} 21 \frac{\min (0,1 ; 2 ; 1 ; 0,1 ; 3)}{2}=\frac{0,1}{2}=0,0500 \\
& \mathrm{R} 31 \frac{\min (0,1 ; 2 ; 1 ; 0,1 ; 3)}{1}=\frac{0,1}{1}=0,1000
\end{aligned}
$$

Berikut adalah perhitungan kriteria yang bernilai benefit.

$$
\begin{aligned}
& \mathrm{R} 13 \frac{3}{\max (3 ; 4 ; 3 ; 4 ; 5)}=\frac{3}{5}=0,6000 \\
& \mathrm{R} 23 \frac{4}{\max (3 ; 4 ; 3 ; 4 ; 5)}=\frac{4}{5}=0,8000 \\
& \mathrm{R}^{33} \frac{3}{\max (3 ; 4 ; 3 ; 4 ; 5)}=\frac{3}{5}=0,6000
\end{aligned}
$$

Setelah dilakukan perhitungan maka diperoleh matriks normalisasi seperti tabel 4 .
Tabel 4. Matriks Normalisasi

\begin{tabular}{lrrrr}
\hline \multirow{2}{*}{ Alternatif } & \multicolumn{4}{c}{ Kriteria } \\
\cline { 2 - 5 } & Absensi & Tepat waktu & Kinerja & Kejujuran \\
\hline Darus Salam & 1,0000 & 0,5000 & 0,6000 & 1,0000 \\
Nur Oktaviani & 0.5 & 1,0000 & 0,8000 & 0,8000 \\
Vera Larasati & 0,1000 & 0,2500 & 0,6000 & 0,6000 \\
Murniati & 1,0000 & 0,3333 & 0,8000 & 0,8000 \\
Via Sumantia & 0,3333 & 0,5000 & 1,0000 & 0,8000 \\
\hline Bobot & 0,1207 & 0,0554 & 0,2991 & 0,5248 \\
\hline
\end{tabular}

1. Darus Salam

$=\{(1,000 \times 0,1207)+(0,5000 \times 0,0554)+$

$(0,6000 \times 0,2991)+(1,0000 \times 0,5248)\}$

$=0,1207+0,0278+0,1795+0,5248$

$=0,8527$

2. Nur Oktaviani

$=\{(0,0500 \times 0,1207)+(1,0000 \times 0,0554)+$

$(0,8000 \times 0,2291)+(0,8000 \times 0,5248)\}$

$=0,0061+0,0554+0,1833+0,4198$

$=0,7207$

3. Vera Larasati

$=\{(0,1000 \times 0,1207)+(0,2500 \times 0,0554)+$

$(0,6000 \times 0,2991)+(0,6000 \times 0,5248)\}$

$=0,0120+0,0139+0,1795+0,3149$

$=0,5023$

4. Murniati

$=\{(1,0000 \times 0,1207)+(0,3333 \times 0,0554)+$

$(0,8000 \times 0,2991)+(0,8000 \times 0,5248)\}$

$=0,1207+0,0185+0,2393+0,4198$

$=0,7983$

5. Via Sumantia

$=\{(0,0333 \times 0,1207)+(0,5000 \times 0,0554)+$

$(1,0000 \times 0,2991)+(0,8000 \times 0,5248)\}$

$=0,0040+0,0278+0,2991+0,4198$

$=0,7507$

Sehingga dapat disimpulkan bahwa alternatif dengan nilai yang paling besar adalah Darus Salam sebagai alternatif karyawan terbaik dengan nilai $\mathbf{0 , 8 5 2 7 . ~}$

\subsection{Model Data}

a. Entity Relationship Diagram (ERD)

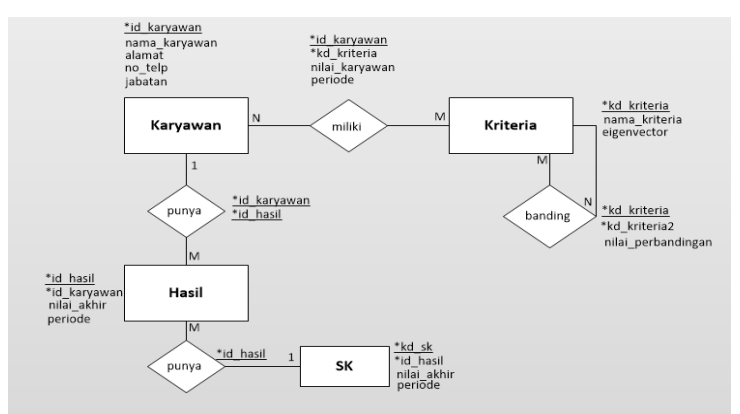

Gambar 4. Entity Relationship Diagram 
Pada gambar 4 adalah Entity Relationship Diagram yang digunakan sebagai gambaran hubungan atau relasi antar entitas yang ada pada database. Berikut adalah ERD dari sistem penunjang keputusan karyawan terbaik pada PT. Energi Sinar Sentosa.

b. Logical Record Structure (LRS)

Menurut Dhanta [5] Logical Record Sructure adalah representasi dari struktur pada tabel dan record yang terbentuk dari hasil himpunan antar entitas. Pada gambar 5 merupakan Logical Record Sructure (LRS) dari sistem penunjang keputusan karyawan terbaik pada PT. Energi Sinar Sentosa.

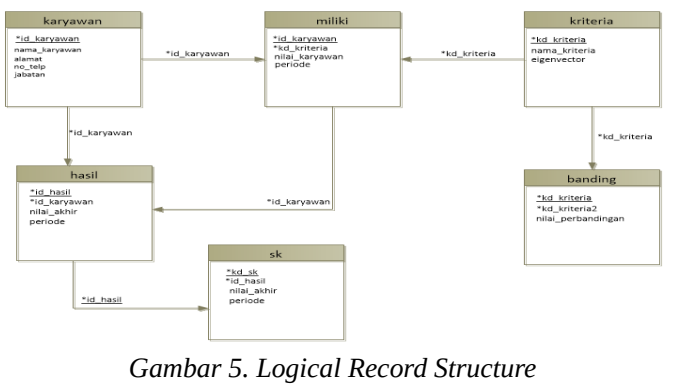

\section{c. Use Case Diagram}

Use case diagram merupakan sebuah diagram yang digunakan untuk menggambarkan interaksi antara pengguna atau user dengan sebuah sistem yang dibuat. Berikut adalah use case diagram dari sistem penunjang keputusan karyawan terbaik pada PT. Energi Sinar Sentosa seperti pada gambar 6,7 dan 8.

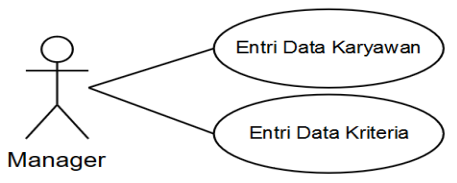

Gambar 6. Use Case Diagram Master

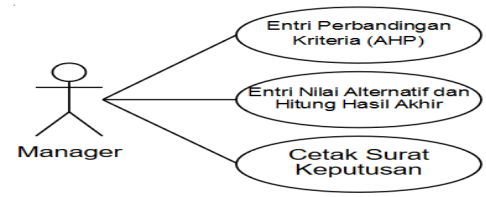

Gambar 7. Gambar 7.Use Case Diagram Transaksi

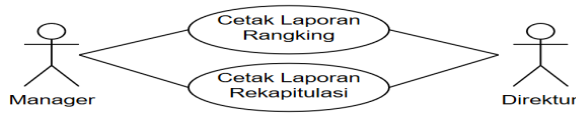

Gambar 8. Use Case Diagram Laporan

d. Rancangan Layar
Berikut adalah rancangan layar yang pada sistem penunjang keputusan karyawan terbaik.

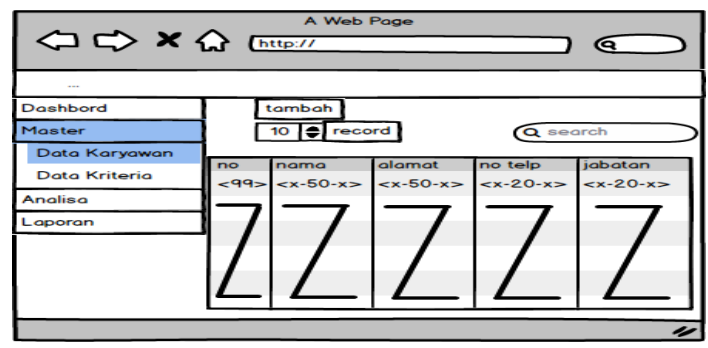

Gambar 9. Rancangan Layar Master Karyawan

Pada gambar 9 adalah rancangan layar pada master data karyawan yang digunakan untuk menginput dan menampilkan data karyawan.

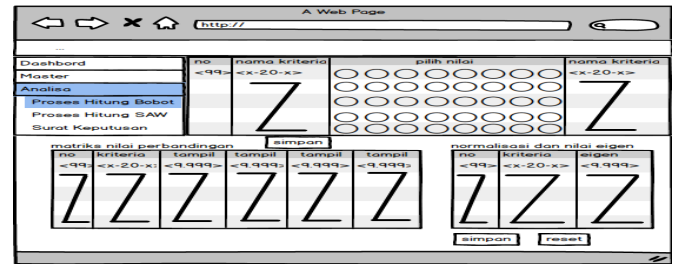

Gambar 10. Rancangan Layar Proses Hitung Bobot

Pada gambar 10 adalah rancangan layar pada proses hitung bobot yang digunakan untuk membandingkan tingkat kepentingan antar kriteria untuk mencari bobot dengan metode AHP.

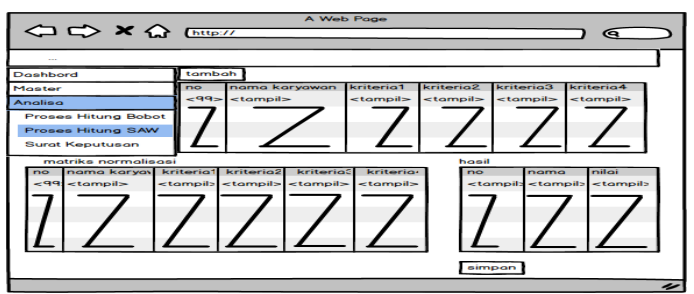

Gambar 11. Rancangan Layar Proses Hitung Hasil Akhir

Pada gambar 11 adalah rancangan layar pada proses hitung hasil akhir yang digunakan untuk menginput nilai karyawan dan menghitung nilai akhir dengan metode SAW.

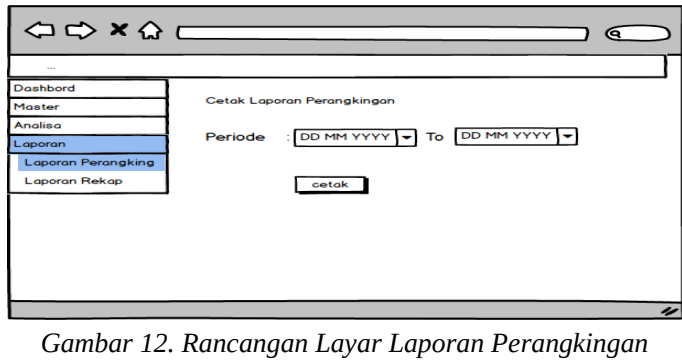

Pada gambar 12 adalah rancangan layar pada Laporan perangkingan yang digunakan untuk mencetak laporan perangkingan. 


\subsection{Hasil Penelitian}

Setelah melalui tahap perhitungan bobot dengan metode Analytical Hierarchy Process (AHP) dan menghitung keseluruhan nilai ahir dan perangkingan dengan metode Simple Additive Weighting (SAW) maka diperoleh nilai alternatif dari urutan tertinggi hingga terkecil dalam penelitian pada PT. Energi Sinar Sentosa seperti tabel 5:

Tabel 5. Hasil Penelitian

\begin{tabular}{llll}
\hline No & Nama & Nilai & Rangking \\
\hline 1. & Darus Salam & 0,8527 & 1 \\
2. & Murniati & 0,7983 & 2 \\
3. & Via Sumantia & 0,7505 & 3 \\
4. & Nur Oktaviani & 0,7207 & 4 \\
5. & Vera Larasati & 0,5023 & 5 \\
\hline
\end{tabular}

\section{KESIMPULAN}

Berdasarkan penelitian yang telah dilakukan pada PT. Energi Sinar Sentosa, maka didapatkan kesimpulan sebagai berikut :

a. Dengan dibuatnya sistem ini maka akan memudahkan manager dalam mengambil keputusan untuk menentukan karyawan terbaik.

b. Dengan adanya metode Analytical Hierarchy Process (AHP) untuk menentukan bobot dan metode Simple Additive Weighting (SAW) sebagai proses penilaian ranking karyawan sesuai dengan nilai kriteria yang telah ditentukan sehingga hasil penilaian menjadi lebih maksimal.

c. Berdasarkan surat persetujuan kriteria yang telah diajukan kepada perusahaan, maka telah ditetapkan 4 (empat) kriteria dan telah disetujui oleh Manager dengan kriteria yang masing-masing memiliki bobot absensi 0,1207, tepat waktu 0,0554, kinerja 0,2991 dan kejujuran 0,5248. Dengan nilai eigenvector yang sudah konsisten dan tidak perlu dilakukan perhitungan ulang dengan nilai Consistency Ratio (CR) yaitu, 0,0254.

\section{DAFTAR PUSTAKA}

[1] Hasugian, H., Sabila, Z.N., Penerapan Metode AHP dan SAW Dalam Pengambilan Keputusan Pemilihan Supplier Bahan Jaket Pada CV. Widia Pratama Kreasi. Prosiding Seminar Nasional Teknologi Informasi Universitas Ibn Khaldun Bogor 2018, pp322-328.

[2] Astuti, Y., Fuad, I.Z., Penentuan Karyawan Terbaik Menggunakan Simple Additive Weighting pada PT. Patra Nur Alaska. Seminar Nasional Teknologi Informasi dan Multimedia 2017, pp36-41.

[3] Rikki, A., Marbun, M., Siregar, J.R., Sistem Pendukung Keputusan Penerimaan Karyawan Dengan Metode SAW pada PT. Karya Sahata
Medan. Journal of Informatics Pelita Nusantara 2016, pp38-46.

[4] Marimin, Maghfiroh, N., Aplikasi Teknik Pengambilan Keputusan dalam Manajemen Rantai Pasok, UPB 2010.

[5] Junianto, E., Primaesha Y., Perancangan Sistem Tracking Invoice Laboratorium PT. Sucufindo. Informatika Vol 2, 2015, No 2. 